\title{
First report of infestation of cassava fruit, Manihot esculenta, by Neosilba perezi (Romero \& Ruppell) (Lonchaeidae) in Brazil
}

\author{
Strikis, PC. ${ }^{a}$, Marsaro Júnior, AL. ${ }^{b}$, Adaime, $R .^{c *}$ and Lima, CR. ${ }^{d}$ \\ andependent Researcher, Americana, SP, Brazil \\ ${ }^{\mathrm{b}}$ Embrapa Trigo, Passo Fundo, RS, Brazil \\ 'Embrapa Amapá, Rod. JK, Km 5, 2600, CEP 68903-419, Macapá, AP, Brazil \\ dUniversidade do Estado do Amapá - UEAP, Macapá, AP, Brazil \\ *e-mail: adaime@cpafap.embrapa.br
}

Received October 5, 2011 - Accepted January 23, 2012 - Distributed August 31, 2012

(With 1 figure)

Neosilba perezi (Romero \& Ruppell) is considered to be a leaf bud pest of cassava, Manihot esculenta, that can reduce the yield of tubers (Lourenção et al., 1996) and the quality of propagation materials (Farias et al., 2007).

A total of 188 fruits $(0.38 \mathrm{~kg})$ of cassava, M. esculenta, were collected in the municipality of Ponte Nova, Minas Gerais, Brazil (20 24' 39' S and 42 ${ }^{\circ} 55^{\prime} 15^{\prime}$ ' W; $456 \mathrm{~m}$ ) in July, 2011. The fruit was counted, weighed and stored in screen-covered plastic trays containing vermiculite and kept at room temperature. The substrate was sifted daily and the obtained puparia were stored in flasks containing moist vermiculite. The emerged adults were preserved in $70 \%$ ethanol and identified using the identification keys published by Zucchi (2000), Canal and Zucchi (2000), and McAlpine and Steyskal (1982). Voucher specimens were deposited in the collections of Embrapa Amapá (Tephritidae and Braconidae) and in the personal collection of the first author (Lonchaeidae).

A total of 40 puparia were obtained from the collected fruit. The specimens emerged from these puparia were Tephritidae ( 9 females of Anastrepha montei Lima, 4 females

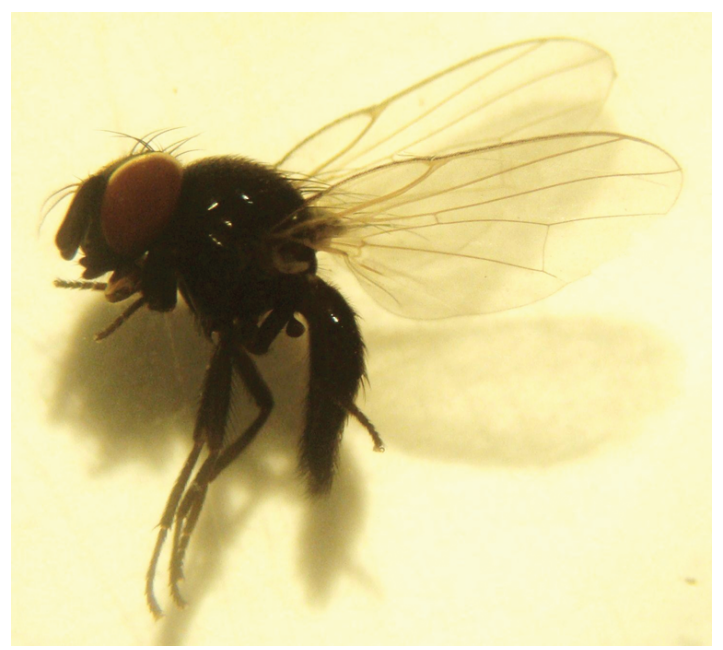

Figure 1. Male of Neosilba perezi (Romero \& Ruppell). Photo: Alberto Luiz Marsaro Júnior. of Anastrepha pickeli Lima, 13 males of Anastrepha), Lonchaeidae [1 male of Neosilba perezi (Romero \& Ruppell) (Figure 1)], and Braconidae [1 female and 1 male of Utetes anastrephae (Viereck)]. These species of Tephritidae and Braconidae had already been obtained from cassava fruit collected in the Brazilian state of Minas Gerais (Alvarenga et al., 2009). However, this is the first report of $N$. perezi in cassava fruits in Brazil. Up until now, the species had been obtained only from leaf buds, as shown in the work by Gisloti and Prado (2011).

Although this work obtained only one male of N. perezi in cassava fruit, this fact demonstrates the plasticity of the species in that its larvae are able to occupy different niches, namely fruit and apical leaf buds. Hence, if adequate apical buds are in low supply for larval feeding, the species is able to maintain itself by feeding on fruit. Moreover, the fact that the presence of $N$. perezi in fruit was previously unknown enables the species to evade the pest control method currently used by agriculturists (removal of infested buds).

We emphasize that more intensive collection work is required in order to enable the molecular analysis of individuals obtained from fruit and leaf buds, preferably collected at the same location where this work was performed, as an incipient process of speciation may be taking place. This would also make it possible to observe whether the infestation of the two host plant structures is synchronous.

Acknowledgements - We would like to thank the Conselho Nacional de Desenvolvimento Científico e Tecnológico - CNPq for the Research Productivity Fellowship granted to RA and the Undergraduate Research Fellowship granted to CRL.

\section{References}

ALVARENGA, CD., MATRANGOLO, CAR., LOPES, GN., SILVA, MA., LOPES, EM., ALVES, DA., NASCIMENTO, AS. and ZUCCHI, RA., 2009. Moscas-das-frutas (Diptera: Tephritidae) e seus parasitóides em plantas hospedeiras de três municípios do norte do estado de Minas Gerais. Arquivos do Instituto Biológico, vol. 76, no. 2, p. 195-204.

CANAL, NA. and ZUCCHI, RA., 2000. Parasitóides - Braconidae. In MALAVASI, A. and ZUCCHI, RA. (Ed.). Moscas-das-frutas 
de importância econômica no Brasil: conhecimento básico e aplicado. Ribeirão Preto: Holos. p. 119-126.

FARIAS, ARN., FERREIRA FILHO, JR. and MATTOS, PLP., 2007. Mosca-do-broto e efeito do ataque em cultivares de mandioca. Available from: <htttp://infobibos.com/artigos/2007_4/mandioca/ index.htm>. Access in: 09 dez. 2009.

GISLOTI, L. and PRADO, AP., 2011. Cassava shoot infestation by larvae of Neosilba perezi (Romero \& Ruppell) (Diptera: Lonchaeidae) in São Paulo State, Brazil. Neotropical Entomology, vol. 40, no. 3, p. 312-315. Pmid:21710026. http://dx.doi.org/10.1590/ S1519-566X2011000300004
LOURENÇÃO, AL., LORENZI, JO. and AMBROSANO, GMB., 1996. Comportamento de clones de mandioca em relação a infestação por Neosilba perezi (Romero \& Ruppell) (Diptera: Lonchaeidae). Scientia Agricola, vol. 53, no. 2-3, p. 304-309.

McALPINE, JF. and STEYSKAL, GC., 1982. A revision of Neosilba McAlpine with a key to the world genera of Lonchaeidae (Diptera). The Canadian Entomologist, vol. 114, no. 2, p. 105-138. http://dx.doi.org/10.4039/Ent114105-2

ZUCCHI, RA., 2000. Taxonomia. In MALAVASI, A. and ZUCCHI, RA. (Eds.). Moscas-das-frutas de importância econômica no Brasil: conhecimento básico e aplicado. Ribeirão Preto: Holos. p. 3-24. 